Dzieje Najnowsze, Rocznik L - 2018, 1

PL ISSN 0419-8824

Magdalena Gibiec

Uniwersytet Wrocławski

\title{
Bezpieczeństwo na granicy. Aktywność OUN w latach 1930-1935 na podstawie sprawozdań sytuacyjnych (Wschodnio)małopolskiego Inspektoratu Okręgowego Straży Granicznej*
}

\begin{abstract}
Abstrakt: W niniejszym artykule nakreślono działalność Organizacji Ukraińskich Nacjonalistów na terenie pogranicza polsko-czechosłowackiego i jej wpływu na tamtejszą ludność. Na podstawie meldunków sytuacyjnych Małopolskiego Inspektoratu Okręgowego Straży Granicznej, wytworzonych w latach 1930-1935, starano się ukazać metody zapobiegania aktywności OUN zagrażającej bezpieczeństwu państwa, a także prześledzić sytuację narodowościową na pograniczu.
\end{abstract}

Słowa kluczowe: Straż Graniczna, bezpieczeństwo wewnętrzne, ukraiński nacjonalizm, tożsamość, pogranicze.

Abstract: The present article outlines the activity of the Organization of Ukrainian Nationalists in the area of Polish-Czechoslovak borderland and its impact on the local people. On the basis of situation reports of the Lesser Poland Regional Inspectorate of the Border Guard, issued between 1930 and 1935, an attempt was made both to present the methods of prevention of the OUN operations that threatened the security of the Polish State, and to track a nationality situation in the borderland.

Key w ords: Border Guard, internal security, Ukrainian nationalism, identity, borderland.

\footnotetext{
* Powstanie artykułu było możliwe dzięki finansowemu wsparciu Wydziału Nauk Historycznych i Pedagogicznych Uniwersytetu Wrocławskiego w ramach konkursu na dofinansowanie projektów badawczych młodych naukowców i uczestników studiów doktoranckich (nr projektu 0420/1581/16).
} 


\section{Wprowadzenie}

Po odzyskaniu niepodległości w 1918 r. podstawowym celem polskiej polityki stały się odbudowa państwa oraz zapewnienie bezpieczeństwa, co zagwarantować miało m.in. ostateczne ustalenie granic. O przynależności Warmii i Mazur rozstrzygną plebiscyt, spór z Czechosłowacją o Ślask Cieszyński zakończył się niepowodzeniem, plebiscyt i trzy powstania zadecydowały o położeniu Górnego Ślaska. Wschodnie granice II Rzeczypospolitej kształtowały się natomiast $\mathrm{w}$ warunkach rewolucji, które rozgrywały się w owym czasie na terytorium Europy Wschodniej i Środkowej. Rewolucje te pobudziły do działania całe narody i przyśpieszyły formowanie ich świadomości, czego skutkiem było powstanie nowych państw. Na wschód od Zbrucza Ukraińcy stworzyli Ukraińską Republikę Ludowa, która została w niedługim czasie pokonana przez bolszewików, a jej tereny stały się częścią marionetkowej Ukraińskiej Socjalistycznej Republiki Radzieckiej (USRR). Ukraińcy na zachodzie natomiast cała energię skupili na walce o przyznanie im Galicji Wschodniej ${ }^{1}$. Klęska zakończyły się jednak walki z Polakami o Lwów prowadzone przez Zachodnioukraińską Republikę Ludowa. Po wojnie nawet najbardziej liberalne władze polskie granice ewentualnego państwa ukraińskiego wyznaczały na wschód od rzeki Zbrucz ${ }^{2}$. 25 VI 1919 r. przekazano Polsce Galicję Wschodnia pod tymczasowy zarząd, a decyzją Rady Ambasadorów 15 III 1923 r. teren ten ostatecznie stał się polski, otoczony przez trzech sasiadów: Czechosłowację, Rumunię oraz ZSRR. Wszystkie te państwa mierzyły się z dążeniami niepodległościowymi mniejszości ukraińskiej, która je zamieszkiwała. Ludność ta stanowiła ok. $15 \%$ populacji państwa polskiego. Nastroje społeczne wśród Ukraińców sprzyjały radykalizacji ich poglądów i doprowadziły do wzrostu znaczenia ideologii nacjonalizmu. Już w 1920 r. doszło do powołania Ukraińskiej Organizacji Wojskowej (UWO), która postawiła sobie za cel kontynuowanie walk o oderwanie Kresów od Polski metodami o wiele bardziej radykalnymi. Jej działacze występowali nie tylko przeciw Polakom, ale również i Ukraińcom skorym do ugody z rządem polskim. W 1929 r. doszło do konsolidacji środowisk nacjonalistycznych i powstania Organizacji Ukraińskich Nacjonalistów (OUN), której UWO pozostawała ramieniem

\footnotetext{
${ }^{1}$ Istotne, z punktu widzenia proponowanego tematu, jest rozróżnienie pojęć „Małopolska Wschodnia” oraz „Galicja Wschodnia”. Należy podkreślić, że to pierwsze pojęcie de facto obowiązywało w administracji II Rzeczypospolitej Polskiej. „Galicja Wschodnia” znajdowała się natomiast $\mathrm{w}$ powszechnym użyciu, a także - z perspektywy badacza stosunków polsko-ukraińskich - wydaje się terminem najbardziej neutralnym. Warto przy tym zauważyć, że teren Galicji Wschodniej nie pokrywał się dokładnie z Małopolską Wschodnia, a mianowicie był okrojony o kilka powiatów województwa lwowskiego. Dla uproszczenia jednak w dalszej części artykułu oba terminy występują naprzemiennie.

2 R. Wysocki, Organizacja Ukraińskich Nacjonalistów w Polsce w latach 1929-1939, Lublin 2003, s. 33.
} 
zbrojnym (do 1933 r., kiedy została wchłonięta przez OUN). Organizacje te były przeszkodą (choć nie jedyna) w osiagnięciu sukcesu na polu porozumienia z mniejszością ukraińską oraz zapewnienia bezpieczeństwa w kraju ${ }^{3}$. W kontekście powyższego ochrona granic stała się jednym z priorytetów polityki państwa polskiego. Zapewnienie bezpieczeństwa wewnętrznego na granicach II RP było kluczowym warunkiem stabilizacji i integralności państwa. Władze, od najwyższego do najniższego szczebla, współdziałały w celu zlokalizowania i unicestwienia czynników zagrażajacych spokojowi. Na granicy w omawianym okresie powstał dwoisty system, który dzielił państwo na część wschodnia (zabezpieczana przez Korpus Ochrony Pogranicza - KOP) oraz północna, zachodnią i południowa, nad którymi pieczę sprawowała Straż Graniczna.

Lata 1930-1935 nie zostały wybrane przypadkowo i tworzą pewien odrębny etap w stosunkach polsko-ukraińskich. W 1930 r. doszło do pacyfikacji mniejszości ukraińskiej w odpowiedzi na masowe sabotaże ze strony nacjonalistów z organizacji UWO-OUN. Wydarzenia te były częścią ogólnego kryzysu politycznego i parlamentarnego $\mathrm{w}$ kraju. $\mathrm{W}$ tym roku zarządzono również tzw. wybory brzeskie, w wyniku których aresztowano znaczacych działaczy ukraińskich, przez co nie udało się wprowadzić do rządu wielu przedstawicieli z Ukraińskiej Reprezentacji Parlamentarnej. Jej członkowie, którzy stanowili silną pozycję w społeczeństwie ukraińskim, kontrolowali instytucje gospodarcze i kształtowali opinię publiczna. Wpływy te jednak były ograniczane przez coraz większą aktywność nacjonalistów z UWO-OUN. Wszystko to działo się nie w oderwaniu od skutków kryzysu gospodarczego z 1929 r., który w konsekwencji doprowadził do nasilenia konfliktów społecznych, również na tle narodowościowym. Warto także zwrócić uwagę na szerszy kontekst międzynarodowy. Z punktu widzenia niniejszego artykułu kluczowe były stosunki Polski z Czechosłowacja, które mimo wzajemnej niechęci uległy w tych latach polepszeniu, głównie ze względu na współpracę wywiadów obu państw. Skutkowało to przyhamowaniem kontaktów rządu w Pradze z działaczami OUN, co jednocześnie spowodowane było także postępującym zbliżeniem nacjonalistów ukraińskich z III Rzesza. Zakulisowo nie zaprzestano jednak całkowicie wspierania tego ruchu. Z kolei rok 1935 to data śmierci Józefa Piłsudskiego, po której nastapił kolejny zwrot $\mathrm{w}$ polityce państwa wobec mniejszości narodowych.

Niniejszy artykuł skupia się na stosunkowo niewielkim odcinku, który rozgraniczał tereny Małopolski Wschodniej od czechosłowackiej Rusi Zakarpackiej, dlatego też jego podstawą są materiały wytworzone przez (Wschodnio)małopolski Inspektorat Okręgowy Straży Granicznej na przestrzeni lat 1930$1935^{4}$, znajdujące się w Centralnym Państwowym Archiwum Historycznym

${ }^{3}$ Udział w tym miała również Komunistyczna Partia Zachodniej Ukrainy (KPZU), której działalność zasługuje na osobne opracowanie.

${ }^{4}$ W 1934 r. Małopolski Inspektorat Okręgowy Straży Granicznej został podzielony na część wschodnią z siedzibą we Lwowie oraz zachodnią z siedzibą w Krakowie. Z punktu widzenia 
Ukrainy we Lwowie (ukr. Centralnyj Derżawnyj Istorycznyj Archiw Ukrainy u Lwowi - CDIAUL). Wybór tego odcinka został dokonany zarówno ze względu na dynamikę kontaktów nacjonalistów po obu stronach (choć tereny Gdańska i Śląska Cieszyńskiego odznaczały się pod tym względem większa aktywnościa), jak i przez wzgląd na specyfikę terenu i relacji między galicyjskimi Ukraińcami a tymi zamieszkałymi na terenie Rusi Zakarpackiej. Kluczowa wydaje się odpowiedź na pytania: w jak dużym stopniu nielegalne organizacje ukraińskie wpływały na kształt ochrony granicznej, a także na mieszkańców po obu stronach granicy? Jak Straż Graniczna przedstawiała Ukraińców w sprawozdaniach? Jaki był udział OUN w kształtowaniu tożsamości Ukraińców zamieszkujących pogranicze?

\section{Straż Graniczna wobec działań OUN}

Straż Graniczna formalnie została powołana 22 III 1928 r. rozporządzeniem Prezydenta RP Ignacego Mościckiego ${ }^{5}$, które regulowało jej zadania, kompetencje i ustrój wewnętrzny ${ }^{6}$. Zgodnie z art. 2: „Straż Graniczna stanowi jednolita, zorganizowana na zasadach obowiązujacych w wojsku formację, podległa Ministrowi Skarbu i jest w zakresie ochrony celnej organem wykonawczym władz skarbowych [...] w zakresie zaś ochrony granic państwa [...] organem wykonawczym władz administracji ogólnej” (podlegała więc również Ministerstwu Spraw Wewnętrznych) ${ }^{7}$. Mimo że z zadań postawionych przed tą formacja jasno wynikało, iż jej głównym obowiązkiem była ochrona granic pod katem celnym, to jednak obserwacje zawarte w meldunkach sytuacyjnych oraz dodatkowych rozkazach, a także zakres działań i konieczność współpracy z Policją Państwowa czy wywiadem wojskowym wskazywały na jej niemała rolę $\mathrm{w}$ zapewnieniu bezpieczeństwa wewnętrznego państwa pod katem politycznym.

Siedziba Małopolskiego Inspektoratu Okręgowego Straży Granicznej znajdowała się w Przemyślu. Interesująca, z punktu widzenia niniejszego artykułu, jest jedynie jego część składająca się z trzech inspektoratów granicznych: Stryj, Sambor oraz Kołomyja, a której podlegał południowy odcinek graniczny z Czechosłowacją i Rumunią o łącznej długości $650 \mathrm{~km}$. 17 XII 1934 r. doszło do reorganizacji Małopolskiego Inspektoratu Okręgowego Straży Granicznej i podziału na Zachodnio- oraz Wschodniomałopolski Inspektorat Okręgowy Straży Granicznej z siedzibami w Krakowie oraz we Lwowie. Praca

niniejszego artykułu interesujący jest jedynie odcinek, który w 1934 r. znalazł się w zakresie działań Wschodniomałopolskiego Inspektoratu Okręgowego Straży Granicznej.

${ }^{5}$ Rozporządzenie Prezydenta Rzeczypospolitej z dnia 22 marca 1928 r., „O Straży Granicznej”, Dz.U. 1928, nr 37, poz. 349.

${ }^{6}$ H.M. Kula, Polska Straż Graniczna w latach 1928-1939, Warszawa 1994, s. 45.

7 Ibidem, s. 46. 
wywiadowcza prowadzona była w owym okresie przez Ekspozyturę Oddziału II Sztabu Komendy Straży Granicznej (KSG), którą w 1934 r. zmieniono na Oddział Informacyjny KSG ${ }^{8}$. Należy podkreślić, że główne zadanie wywiadu Straży Granicznej stanowiły wykroczenia skarbowo-celne i to na nich skupiała swoją uwagę. Dopiero w 1934 r. pojawiły się osobne meldunki dotyczące osób politycznie podejrzanych na granicy. Zadaniem wywiadowców była inwigilacja środowisk politycznych oraz działań mniejszości, a także sondowania nastrojów ludności na pograniczu, jednak bez podejmowania konkretnych działań ${ }^{9}$. Informacje o podejrzanych osobach i organizacjach (działajacych $\mathrm{w}$ pasie o szerokości $30 \mathrm{~km}$ przy granicy) zapisywano $\mathrm{w}$ specjalnych arkuszach ewidencyjnych, które miały służyć Oddziałowi II Sztabu Generalnego Wojska Polskiego ${ }^{10}$. Straż Graniczna utrzymywała również ścisłe kontakty z Policją Państwową i była wykorzystywana w akcjach policyjnych przeciwko nielegalnym manifestacjom, strajkom i innym działaniom wpływającym na bezpieczeństwo. Mimo znajomości szlaków, którymi przemycano nielegalne pisma i broń, w większości sytuacji Straż Graniczna była bezskuteczna. Wiedziano m.in. o czechosłowackim mieście Chust, z którego wychodził przemyt w kierunku polskim, jednak „mimo wielkiej czujności ze strony Straży Granicznej przemytu dotychczas żadnego bibuły antypaństwowej nie przytrzymano" ${ }^{11}$. Powodem tego stanu rzeczy były z pewnością braki kadrowe, jak i niskie morale, a także ubytki w podstawowym wyposażeniu, wywołane sytuacją materialną. Nierzadko zdarzało się, że wywiadowcy odbywali służbę w mundurze, nie mając na zmianę żadnej cywilnej odzieży, co zdecydowanie nie sprzyjało pracy wywiadowczej ${ }^{12}$. Natomiast zwiększona czujność na granicach w okresie wzmożonych akcji antypaństwowych doprowadzała do sytuacji, w której strażnicy służyli po 10-12 godzin dziennie przez cały miesiąc, bez ani jednego dnia wolnego, co w połaczeniu z opadami atmosferycznymi wywoływało wyczerpanie i zobojętnienie skutkujące brakiem czujności ${ }^{13}$.

$\mathrm{Z}$ powodu ograniczeń etatowych oraz konieczności codziennej obserwacji spore znaczenie miało posługiwanie się informatorami i konfidentami. Sposób ten gwarantował zwiększoną skuteczność w wykryciu przestępstw. Jednak

${ }^{8}$ B.a., Straż Graniczna 1928-1939. Zadania i rozwój, http://www.emeryci-sg.org.pl/historia/ sg/sg_dwa_rp.html (dostęp: 15 XI 2016).

${ }^{9}$ H.M. Kula, op. cit., s. 48-49.

${ }^{10}$ Centralne Państwowe Archiwum Historyczne Ukrainy we Lwowie (dalej: CDIAUL), f. 204, op. 1, spr. 714, Charakterystyka terenu, Komisariat Straży Granicznej Ludwikówka, 14 I 1935, k. 19.

${ }^{11}$ Ibidem, spr. 713, Charakterystyka terenu Komisariatu Straży Granicznej Sołotwina przesłana na rozkaz Kierownika Inspektoratu Straży Granicznej Stryj, 17 I 1935, k. 1.

12 Ibidem, spr. 342, Meldunek sytuacyjny nr 19/30 na 5 VII 1930, Inspektorat Straży Granicznej, Krosno 4 VII 1930, k. 26.

${ }^{13}$ Ibidem, spr. 535, Wniosek Inspektoratu Granicznego Stryj do Małopolskiego Inspektoratu Okręgowego Straży Granicznej w sprawie zmniejszenia czasu służby, Przemyśl 8 IX 1933, k. 16 . 
pozyskanie osób lojalnych wobec państwa, których jedyną motywacją nie była chęć zarobku (co w czasie biedy spowodowanej ówczesnym kryzysem gospodarczym nastręczało trudności), stanowiło problem, który rzutował na sukces potencjalnych operacji. Powszechna była jednak zapłata za sprawdzone informacje, o czym świadczy następujący rozkaz: „winien posiadać Kierownik Komisariatu specjalny fundusz dyspozycyjny na wydatki związane ze służba wywiadowcza, np. - urabianie konfidentów, otrzymywane informacje od przygodnych donosicieli - wszystko to jest połączone z wydatkami pieniężnymi" ${ }^{14}$. Nierzadko, szczególnie w kontaktach ze strażą czechosłowacka, donosiciele o wiele chętniej udzielali informacji, „gdy zostana potraktowani, czy to wódka, piwem, papierosami czy też innymi poczęstunkami”' ${ }^{15}$. Mimo ostrożności w doborze konfidentów, sporej rotacji i skrupulatnego sprawdzania posiadanych przez nich informacji nie udało się uniknąc prowokatorów, którzy działali jedynie dla własnego pożytku. Przykładowo Piotr Tytuk podając się za kuriera OUN, wszedł w posiadanie 450 egzemplarzy czasopisma „Surma”, które przywiózł z Czechosłowacji. Spodziewano się, że będzie usiłował „posiadany materiał wyzyskać dla prowokacji i osiagnać w ten sposób korzyści materialne jako konfident, różnych władz, do których będzie się prawdopodobnie zwracał ze swoimi propozycjami"16. Pomocny okazywał się również tzw. kalendarz ukraińskiego nacjonalisty, zawierajacy terminy rocznic narodowych, podczas których UWO-OUN planowało natężone akcje sabotażowe bądź propagandowe ${ }^{17}$ :

Organizacja ukraińskich Nacjonalistów w okresach, kiedy siły policyjne zaabsorbowane sa jakimiś specjalnymi czynnościami, usiłuje wykorzystać takie momenty do akcji dywersyjnej. [...] Dzień 29 i 30 kwietnia jako też 1 maja br. mogą być zatem przez OUN wykorzystane jak że organizacja ta może się liczyć z tym, iż cała uwaga organów policyjnych będzie nastawiona przeciw robocie komunistów. W dniach tych należy wziąć pod uwagę możliwość napadów rabunkowych na urzędy i ambulanse pocztowe, przewożące w tym czasie pieniądze do wypłat pensji. [...] Dzień 2 i 3 maja może wykorzystać OUN do demonstracji jak wywieszanie transparentów o treści antypaństwowej, niszczenie godeł i szyldów urzędów antypaństwowych, podpalenia itp. by zakłócić w ten sposób uroczysty nastrój święta państwowego ${ }^{18}$.

Blisko tych dat wzmagano czujność na granicach, o czym świadczyły nadchodzące rozkazy ${ }^{19}$. Straż Graniczna musiała działać szczególnie szybko

${ }^{14}$ Ibidem, spr. 608, Rozkaz Komisariatu Straży Granicznej Worochta, k. 3.

${ }^{15}$ Ibidem.

${ }_{16}$ Ibidem, spr. 538, Komenda Wojewódzka P.P. Urząd Śledczy Stanisławów, 19 XII 1933, k. 1.

${ }^{17}$ R. Litwiński, Policja wobec UWO i OUN w II Rzeczpospolitej, „Biuletyn Instytutu Pamięci Narodowej" 2010, nr 12 (121), s. 82.

${ }_{18}$ CDIAUL, f. 204, op. 1, spr. 535, Rozkaz Komendanta Wojewódzkiego P.P., Wydział Śledczy, do pana Komendanta P.P. m. Lwowa, Lwów 26 IV 1933, k. 1.

${ }^{19}$ Ibidem, spr. 472, Rozkaz Kierownika Małopolskiego Inspektoratu Okręgowego Straży Granicznej rozesłany do Kierowników Inspektoratów Granicznych Jasło, Sambor, Stryj, Kołomyja, Przemyśl 1 II 1932, k. 1. 
w wyniku podejrzenia o planowanych zamachach lub ucieczce za granice osób podejrzanych o popełnienie zbrodni. Tak np. ścigano Zenona Kossaka z Drohobycza, który oskarżony był o zabójstwo Tadeusza Hołówki oraz napad na pocztę w Truskawcu 8 VIII 1931 r. Zdjęcia oraz rysopis rozesłano do wszystkich oddziałów Straży i KOP ${ }^{20}$. Przydatna była również współpraca ze strażą i żandarmerią czechosłowacka.

Po przejęciu kierownictwa nad krajowym OUN przez Stepana Banderę w 1933 r., postawiono na organizację akcji o zasięgu masowym, aby wciagnać w działalność szersze warstwy społeczne. Jednym z takich działań była akcja szkolna rozpoczęta we wrześniu 1933 r. Polegała one głównie na włamywaniu się do szkół i wyrzucaniu oraz niszczeniu godła, portretów prezydenta czy marszałka Piłsudskiego, usuwaniu napisów w języku polskim. W związku z akcja, prowadzona przez działaczy OUN i związanych z nimi nauczycielami, wydano bardzo szczegółowe rozkazy zapobiegania jej na granicy:

[...] należy rozwinąć jak najenergiczniejszą akcję wywiadowczą przez plac. II linii i podoficerów wywiadu. W celu ustalenia czy na tamtejszym terenie nie szerzy się agitacja [...]. W miejscowościach, gdzie nauczyciele są ukraińscy podejrzani o sprzyjanie ruchowi OUN, należy poddać ich obserwacji czy ci nie prowadza podobnej roboty między mieszkańcami. Następnie należy ustalić kontakty między nauczycielami, względnie działaczami ukraińskimi zamieszkałymi w miejscowościach przygranicznych w Czechosłowacji a naszymi działaczami OUN. W tym celu należy przeprowadzić wywiad na przedpolu i ustalić w jakich miejscowościach na terenie pasa granicznego $\mathrm{w}$ szkołach zatrudnieni są nauczyciele ukraińscy i zapodać ich nazwiska, ponadto należy ustalić nazwiska wszystkich tzw. emigrantów tj. byłych mieszkańców Małopolski, którzy obecnie mieszkają w gminach przygranicznych i oni to, jak wywiad wykazał, w największym stopniu zajmuja się przemycaniem bibuły na nasz teren. Wejść w kontakt z żandarmerią czeska, która otrzymała od swych władz tajny okólnik, zalecający zwalczanie ruchu ukraińskiego na terenie Rusi Podkarpackiej i przez dobre stosunki z poszczególnymi komendantami posterunków możemy uzyskać cenne informacje $\mathrm{e}^{21}$.

Ze względu na brak szczegółowych danych nie wiadomo, czy akcja prewencyjna podjęta przez Straż Graniczną w porozumieniu z policją i żandarmerią czechosłowacką przyniosła pożądane rezultaty. Istnieje jednak liczbowe zestawienie akcji OUN: powiat stryjski - 76 wypadków wystapień ekspropriacyjnych, powiat doliński - 20, powiat nadwórniański - 7, Ławoczne 1 akcja. W niektórych powiatach nie doszło do żadnych akcji antyszkolnych, co strażnicy przypisywali swojej skuteczności ${ }^{22}$.

${ }^{20}$ Ibidem, spr. 439, Rozkaz przesłany z Małopolskiego Inspektoratu Straży Granicznej do Kierownika Inspektoratu Straży Granicznej Stryj, 9 IX 1931, k. 1.

${ }^{21}$ Ibidem, spr. 535, Inspektorat Graniczny Stryj, 11 IX 1933, k. 11.

${ }^{22}$ Ibidem, Doniesienia Inspektoratu Granicznego Stryj, Przemyśl 8 I 1934, k. 23. 


\section{Wpływy OUN oraz ogólnej specyfiki terenu na pogranicze}

Pogranicze polsko-czechosłowackie odznaczało się nieco inną specyfika niż tereny położone bliżej centrum państwa. Wskazywały na to m.in. dokumenty przygotowywane przez Straż Graniczna, zawierające charakterystykę terenu w powiatach przygranicznych, z których wyłania się interesująca perspektywa. Przede wszystkim w tamtejszych powiatach mieszkała w przeważającej części ludność ukraińska. Polacy zajmowali niewielki odsetek i stanowili praktycznie tylko warstwę urzędnicza. Przykład mogą stanowić takie miejscowości, jak Perehińsko (7960 Ukraińców wobec 32 Polaków) czy Jasień (3253 Ukraińców wobec 32 Polaków) ${ }^{23}$. Znamienne, że Ukraińcy Ci byli mniej „urobieni społecznie”, jak i „pod względem kulturalno-oświatowym ludność tutejsza nie jest wyrobiona. Jedyną instytucja są Proświty o małej stosunkowo ilości członków. Materiał oświatowy posiadają bardzo skromny, a ludność słabo garnie się do oświaty"24. Działające tam legalne organizacje nie zdobyły takich wpływów, jak w większych ośrodkach miejskich położonych w oddaleniu od granicy. To prowadziło do większej aktywności organizacji antypaństwowych, takich jak OUN czy KPZU, które ze szczególnym natężeniem, walcząc o „rząd dusz”, „zwalczają się nawzajem i są między nimi częste tarcia” OUN współzawodniczyła również z legalna partią Ukraińskie Zjednoczenie Narodowo-Demokratyczne (UNDO), a „działalność jej polega na pogłębieniu różnicy między społeczeństwem ukraińskim i polskim drogą wychowania młodzieży ukraińskiej zgrupowanej w organizacjach kulturalno-oświatowych $\mathrm{w}$ duchu narodowo-szowinistycznym" ${ }^{26}$. Powodów tego stanu rzeczy można wskazać kilka. Z pewnością jednym z nich była bieda. Tereny przygraniczne odznaczały się znacznie gorszymi warunkami ekonomicznymi, szczególnie $\mathrm{w}$ okresie nasilającego się kryzysu gospodarczego. O ile jednak chłopi cała energię poświęcali pracy na polu (,melduję, że z uwagi na intensywne prace na roli/ żniwa, sianokosy itp./ ruch polityczny jest słaby" ${ }^{27}$ ), o tyle bezrobotna inteligencja radykalizowała się i z łatwością wpadała w objęcia OUN.

Należy pamiętać, że granica ustalona ostatecznie w $1921 \mathrm{r}$. w niektórych odcinkach była sztucznym podziałem, następstwem kompromisów rządów sąsiadujących państw, nieuwzględniających specyfiki poszczególnych miejscowości, których mieszkańcy zostali rozdzieleni. W dalszym stopniu łączyły ich więzy rodzinne, sassiedzkie, towarzyskie. Meldunki sytuacyjne zwracały

${ }^{23}$ Ibidem, spr. 1422, Dossier placówki Straży Granicznej Osmołoda, k. 1.

${ }^{24}$ Ibidem, spr. 714, Charakterystyka terenu Komisariatu Straży Granicznej Ławoczne przesłana na rozkaz Kierownika Inspektoratu Straży Granicznej Stryj, 8 I 1935, k. 11.

${ }^{25}$ Ibidem, Charakterystyka terenu Komisariatu Straży Granicznej Ludwikówka przesłana na rozkaz Kierownika Inspektoratu Straży Granicznej Stryj, 14 I 1935, k. 19.

${ }^{26}$ Ibidem.

${ }^{27}$ Ibidem, spr. 598, Meldunek o ruchu osób politycznie podejrzanych na czas 1-31 VIII 1934, Komisariat Straży Granicznej Ławoczne, 31 VIII 1934, k. 35. 
uwagę na codzienne przekraczanie granicy w celu odwiedzin członków rodziny. Takie sytuacje sprzyjały stałym kontaktom oraz wymianie informacji. Wykorzystane zostały również przez nielegalne organizacje, które pod pozorem spotkań prywatnych przenosiły ulotki propagandowe czy poufne informacje państwowe. Jeden ze strażników granicznych powiadamiał, że uzyskał wiadomość, iż „mieszkańcy pogranicza z Czechosłowacji spotykają się z naszymi obywatelami na samej granicy i pod pretekstem pogawędek a nawet tańców z muzyka przekazuja sobie literaturę wywrotową. Ponieważ granica nie jest miejscem na zabawy towarzyskie, polecam bezwarunkowo zabronić wszelkiego kontaktu ludności na granicy" 28 .

Kolejną kwestię, na którą należy zwrócić szczególną uwagę, stanowi tożsamość narodowa na pograniczu. Pod tym względem teren ten jest dosyć skomplikowany. Z jednej strony, w wyniku konfrontacji z innymi, uwypukla się silna identyfikacja $z$ własną grupa i poczucie przynależności. Natomiast z drugiej strony, paradoksalnie, sytuacja taka może rodzić pewnego rodzaju rozmycie tożsamości i asymilację różnych grup. Kwestie te zależą od siły identyfikacji z narodem oraz skuteczności w jej podtrzymywaniu. W tym wypadku niebywała była rola inteligencji, szczególnie jej niższych warstw, księży i nauczycieli, którzy mieli stały kontakt z miejscową ludnością. To poczucie odrębności Ukraińców uwidaczniało się w organizowanych świętach, zbiórkach, wspólnych modlitwach, które prowadziły do systematycznego wzmacniania tożsamości narodowej.

W tym kontekście ciekawym zjawiskiem było, wyraźniejsze niż w pozostałej części Galicji Wschodniej, rozgraniczenie pomiędzy Rusinami i Ukraińcami. Powodem tego mogła być granica z Rusią Zakarpacka, której ludność w większym stopniu identyfikowała siebie jako Rusinów, niż miało to miejsce po polskiej stronie, gdzie było to zjawisko marginalne (choćby grupa skupiona wokół Towarzystwa im M. Kaczkowskiego ${ }^{29}$. Kwestia ta uwidoczniła się także w spisie ludności z 1931 r., podczas którego „,szerzy się agitacja wśród mieszkańców, by ci domagali wypełniania arkuszów spisowych w języku ruskim oraz by podawali narodowość ukraińska, a nie ruska. W wypadku gdyby żądania ludności nie zostały uwzględnione, by ta wstrzymała się od

${ }^{28}$ Ibidem, spr. 546, Inspektorat Graniczny Stryj, 24 X 1933, k. 14. Argumenty te znalazły się także w artykule: M. Gibiec, Proces ksztattowania się tożsamości narodowej na pograniczu polsko-rumuńsko-czechosłowackim w kontekście bezpieczeństwa II Rzeczypospolitej. Analiza dokumentów Inspektoratu Granicznego „Kotomyja” z lat 1928-1935, w: Kołomyja, Pokucie, Huculszczyzna w II Rzeczypospolitej. Wybrane zagadnienia, red. nauk. A.A. Ostanek, A. Smoliński, Warszawa 2017, s. 64-80.

${ }^{29}$ „Na podstawie statystyk wyborczych oraz liczby członków instytucji i stowarzyszeń kulturalnych (Towarzystwo im. Michaiła Kaczkowskiego) oraz gospodarczych (Rewizyjny Zwiąek Ruskich Spółdzielni, Ruskij Rolniczyj Sojuz) pozostających pod wpływami «staroruskimi» można ją [liczbę Rusinów] szacować na 4 do 8\% ogółu populacji ukraińskiej”. G. Hryciuk, Przemiany narodowościowe $i$ ludnościowe $w$ Galicji Wschodniej $i$ na Wołyniu $w$ latach 1931-1948, Toruń 2005, s. 104. 
wszelkich zeznan" ${ }^{30}$. W wyniku tej agitacji w wielu powiatach taka postawa przeważała, a zainteresowanie spisem ludności było bardzo duże. $\mathrm{O}$ tym rozgraniczeniu świadczyć może także przykład ze szkolnej ławy w powiecie leskim, gdzie „w nowo otwartej szkole powszechnej, 30 uczniów złożyło książki wykładowe w języku ruskim, oświadczając nauczycielowi, że z tych książek uczyć się nie będa, gdyż sa to wydania łemkowskie i żądały jednocześnie zaopatrzenia ich w książki wydania ukraińskiego" ${ }^{31}$. Do takiej sytuacji miało dojść w kilku miejscowościach, a jej inicjatorami byli księża greckokatoliccy ${ }^{32}$.

Grupa, o która toczyła się „rywalizacja” między Polakami a Ukraińcami, byli Huculi, licznie zamieszkujacy teren pogranicza. Tak charakteryzował ich jeden ze strażników granicznych: „Jest to plemię górskie, odrębne zwyczajami i kultur od Ukraińców, a używający tylko języka ruskiego. Ze względów politycznych nacjonaliści ukraińscy uważają ich za Ukraińców i w tych duchu przez swych prowodyrów ich uświadamiaja. Akcja ta paraliżowana w skutek energicznej działalności «Towarzystwa Przyjaciół Huculszczyzny» coraz bardziej zanika i huculi uświadamiają się, że stanowią odrębny szczep, związany luźno językiem z narodem ukraińskim" ${ }^{33}$. Agitacja ta miała miejsce po obu stronach granicy, jak wskazuja sprawozdania sytuacyjne: „Dnia 18 VIII br. przybyła wycieczka Ukraińców składająca się z 15 osób, w tym 3 kobiety, do granicy państwa, która udała się wzdłuż linii granicznej po stronie czeskiej do kamienia nr 2 /przedpole Komisariatu Worochta/. Przy wspomnianym kamieniu wycieczka się zatrzymała gdzie odśpiewano kilka piosenek ukraińskich, narodowych. Przewodnikiem wycieczki był Dmytro Klempusz z Jasiny". Wymieniony przewodnik był znanym wszystkim służbom polskim aktywnym członkiem OUN. Natomiast „w miesiącu sierpniu br. zauważono na terenie Komisariatu Worochta wzmożony ruch turystów ukraińskich. Turyści Ci kierowali się przeważnie w kierunku "Czarnomory» i «Żabiego» idąc po 3 i to przeważnie mężczyźni”. Podejrzewając, że ten ruch turystyczny ma na celu „przeciwdziałanie propagandzie Tow. Przyjaciół Huculszczyzny”, zarządzono ścisłą kontrolę i legitymowanie osób podejrzanych w strefie nadgranicznej ${ }^{34}$. Towarzystwo Przyjaciół Huculszczyzny korzystało ze wsparcia władz polskich i miało być przeciwwaga dla ukraińskich organizacji narodowych.

Kolejną kwestią zagrażająca spokojowi było plotkarstwo. Z pozoru wyglądające niewinnie, na pograniczu doszło do rozmiarów, które poważnie niepokoiły Straż Graniczna. Zjawisku temu poświęcano sporo miejsca w meldunkach sytuacyjnych. Peryferyjność obszarów znajdujących się na pograniczu, a co za

${ }^{30}$ CDIAUL, f. 204, op. 1, spr. 416, Inspektorat Straży Granicznej Kołomyja, 9 XII 1931, k. 17.

${ }^{31}$ Ibidem, spr. 669, Meldunek sytuacyjny nr 3/35 za 1-31 III 1935, Inspektorat Straży Granicznej Sambor, 4 IV 1935, k. 30.

${ }^{32}$ Ibidem.

${ }^{33}$ Ibidem, spr. 714, Charakterystyka terenu Komisariatu Straży Granicznej Ludwikówka przesłana na rozkaz Kierownika Inspektoratu Straży Granicznej Stryj, 14 I 1935, k. 19.

${ }^{34}$ Ibidem, spr. 674, Komisariat Straży Granicznej Ludwików, 14 I 1935, k. 47. 
tym idzie słabsza dostępność do sprawdzonych informacji, sprzyjały powstawaniu plotek, nierzadko niebezpiecznych, niepokojących miejscową ludność i wpływających na ich niechętny stosunek do państwa. Rozpowszechniana plotką była zbliżająca się wojna pomiędzy Czechosłowacją a Polską i Rumunia. W czasie strajków chłopskich, w latach 1933-1934, hałas towarzyszący użyciu broni przez oddziały policyjne do ich stłumienia powodował, że gospodarze pobliskich wiosek rozpowiadali, iż „koło Przemyśla rozpoczęła się rewolucja, a w pobliżu słychać już armaty". Groźba wybuchu wojny nabierała coraz większego rozpędu i siała niepokój również wśród strażników, a także powodowała wzajemną nieufność w codziennych kontaktach:

Wśród ludności na przedpolu krąży wersja, że Polska i Węgry maja wypowiedzieć wojnę Czechosłowacji i, że Polacy już się porozumieli z Węgrami odnośnie ustanowienie nowej granicy, która ma sięgać rzekomo do Proszowa. Ponadto u ludności pogranicza Czechosłowacji daje się zauważyć niespotykane dotąd zaniepokojenie spowodowane oczekiwaniem nadzwyczajnych wypadków. Zwiększające się naprężenie w stosunkach wewnętrznych C.S.R. oraz zewnętrznych z Polska, budzi obawy, że lada chwila może wybuchnąc zatarg zbrojny. Potwierdzenie swych przypuszczeń ludność Czechosłowacji znajduje w obostrzonej służbie czeskiej Straży Granicznej i Żandarmerii. Ostatnio szereg strzelań bojowych artylerii czeskiej w Podolincu, których w tym czasie nigdy nie przeprowadzano, budzi nadzieje i obawy ${ }^{35}$.

Rozprzestrzenianie tego typu plotek niosło za sobą odpowiedzialność karna, a niektóre sprawy kierowano do sądu grodzkiego ${ }^{36}$.

Jednym ze sposobów na zaprowadzenie porządku na terenach przygranicznych były wybory samorządowe. O ile w innych częściach Małopolski Wschodniej Ukraińcy stanowili niemały odsetek w samorządzie, o tyle tutaj był to raczej wyjątek, na co wskazywały meldunki: „W ciagu miesiąca marca br. na całym terenie Inspektoratu odbyły się wybory na wójtów. Wójtami zostali wybrani wszędzie Polacy, a w kilku gminach Rusini wypróbowani ze swej lojalności do Państwa Polskiego" ${ }^{37}$. Spotykało się to jednak z szykanami ze strony ukraińskich nacjonalistów, którzy sprzeciwiali się jakiejkolwiek ugodzie z państwem polskim i byli gotowi na wymierzenie najsurowszej kary: „Na podstawie informacji uzyskanych przez Urząd Wojewódzki Lwowski OUN planuje przeprowadzenie akcji mającej na celu bojkot nowo wybranych wójtów lub sołtysów, którzy popierani byli przez władze administracyjne. W razie gdyby bojkot ten nie odniósł skutku, ma być mienie ich podpalone i niszczone. Ponadto OUN szykuje się obecnie do wystapień przeciw tym działaczom i politykom ukraińskim w Polsce, którzy zdaniem przywódców

${ }^{35}$ Ibidem, spr. 682, Meldunek sytuacyjny 10/35 za 1-14 XI 1935, Zachodniomałopolski Inspektorat Okręgowy Straży Granicznej, Kraków, 14 XI 1935, k. 18.

${ }^{36}$ Ibidem, spr. 455, Meldunek sytuacyjny 15/32 na czas od 1 VII do 15 VII 1932, k. 11.

${ }^{37}$ Ibidem, spr. 669, Meldunek sytuacyjny nr 3/35 za 1-31 III 1935, Inspektorat Graniczny Stryj, 4 IV 1935, k. 28. 
OUN prowadzą taktykę ugodową" ${ }^{38}$. Celem tej akcji miało być nie tylko zastraszanie ugodowo nastawionej ludności, ale przede wszystkim wzmocnienie autorytetu OUN, która mianowała się jedyną organizacją niepodległościowa broniąca ukraińskich interesów narodowych, a „legalne partie ukraińskie sprowadziły sprawę narodową na manowce kompromisów i ugód szkodliwych dla narodu ukraińskiego" 39 .

Śmierć Józefa Piłsudskiego była kolejnym wydarzeniem, które pozwoliło członkom OUN snuć przypuszczenia, że nadeszła szansa na wszczęcie walk wyzwoleńczych, w których szala mogła przechylić się na ich stronę. Jeden z Ukraińców miał wyrazić się: „Polaków mordowaliśmy i dalej tak będziemy robić, tym bardziej kiedy zmarł Piłsudski, bo w Polsce wybuchnie zamieszkanie z czego my Ukraińcy skorzystamy" ${ }^{40}$. W 1935 r. doszło także do zawarcia ugody pomiędzy rządem polskim a UNDO. Polityka ta, określana jako „normalizacja”, stwarzała szansę dla legalnych ukraińskich partii i otwierała furtkę demokratycznej obronie sprawy ukraińskiej. Niestety, jeszcze w tym samym roku skończyła się, na rzecz programu „umacniania polskości”, która poniosła fiasko ${ }^{41}$.

\section{Nauczyciele i księża greckokatoliccy współpracujący z OUN}

Na osobną uwage zasługuja niższe warstwy inteligencji, tj. księża greckokatoliccy oraz nauczyciele, którzy odegrali znacząca rolę w budowaniu tożsamości narodowej Ukraińców, a kościół oraz szkoła były miejscami, które wzbudzały zaufanie. Ich działalność w połączeniu z frustracją wynikająca nie tylko z bezrobocia i biedy, ale i sytuacji Ukraińców w II Rzeczypospolitej (nierzadko traktowanych jako obywatele drugiej kategorii), a także niezadowoleniem z braku doraźnych efektów aktywności legalnych organizacji, naturalnie prowadziła ich do radykalizacji i współpracy z OUN. Do odrębnej grupy należały osoby, które działały na rzecz uświadomienia mniejszości ukraińskiej za pomocą legalnych metod, co i tak spotykało się ze sprzeciwem władz polskich wobec nich i w ich oczach nie odróżniało od działaczy OUN. Straż graniczna zwracała uwagę na skuteczność księży w „agitowaniu ludności”, zauważając, że „ludność ruska w północnych gminach powiatu sanockiego, która w 70\% była przekonań staroruskich, zaczyna zmieniać swe poglądy polityczne i czyni przygotowania do stworzenia organizacji

\footnotetext{
${ }^{38}$ Ibidem, spr. 720, Starostwo Powiatowe w Nadwórnej do wszystkich P.P. Komendantów Poster. P.P. powiatu nadwórniańskiego, 5 IV 1935, k. 7.

${ }^{39}$ Ibidem.

${ }^{40}$ Ibidem, spr. 671, Meldunek sytuacyjny 5/35, Wschodniomałopolski Inspektorat Okręgowy Straży Granicznej, Lwów 14 VI 1935, k. 45.

${ }^{41}$ A. Chojnowski, Koncepcje polityki narodowościowej rzadów polskich $w$ latach 1921-1939, Wrocław 1979, s. 206.
} 
ukraińskich. Prowodyrami w tym kierunku są księża grecko-kat. w gminie Czarnorzekach, Rzepniku i Węglówce" 42 . Za osoby odpowiedzialne za zmiany nastrojów społecznych uważano także nauczycieli, przedstawicieli wolnych zawodów i urzędników państwowych ${ }^{43}$.

Doniesienia z powiatów przygranicznych jasno wskazywały na to, że „parochowie” i nauczyciele byli bacznie obserwowani przez Straż Graniczna. Zwracano uwage przede wszystkim na ich kontakty z działaczami OUN, a niektórych podejrzewano o kierowanie ruchem nacjonalistycznym w terenie. Przykładowo do ks. Hawrycza ze wsi Chlebiczyn „stale schodzi się młodzież męska wrogo usposobiona do państwa Polskiego. Rzekomo ma być to związek amatorski teatralny, a w rzeczywistości odbywaja się tam tajne posiedzenia pod przewodnictwem ks. Hawrycza. Również stale bywa u wymienionego księdza niejaki Sołowczuk z Hołostowa, który w r. 1929 karany był za zerwanie orła polskiego ze szkoły i wrzucenie go do ustępu" ${ }^{44}$. Skutecznym orężem stały się kazania, a niejeden ksiądz „nawołując ludzi ażeby nie zapominali, że sa Ukraińcami, zachęcał [ich] do zakładania związków i stowarzyszeń ukraińskich"45. Nie był to przypadek odosobniony, a strażnicy graniczni wskazywali na powtarzające się tego typu wypadki o charakterze antypaństwowym. Greckokatolicki ks. Grzegorz Nowosad z Jaworek głosił podczas kazań, iż czytanie polskich książek oraz gazet jest grzechem ciężkim ${ }^{46}$. Przeciwko wymienionemu księdzu już na początku 1931 r. prowadzono dochodzenie, w którym wykazano, że w szkole ludowej w Jaworkach zabraniał wystawiania przedstawień i mówienia po polsku ${ }^{47}$. W 1934 r. na podstawie kolejnych doniesień wymierzono mu karę miesiąca bezwzględnego aresztu ${ }^{48}$. W innym wypadku ks. Jan Chotyk z Jakutyna miał wyrazić się następujacymi słowami: „Jak nasz Chrystus dziśs zmartwychwstał, tak daj Boże aby nasza Ukraina zmartwychwstała i abyśmy wyleźli z pod tego ciężaru i podłości" ${ }^{49}$. Pewnego rodzaju manifestacją oporu wobec władz był również bojkot uroczystości istotnych dla państwa polskiego.

${ }^{42}$ CDIAUL, f. 204, op. 1, spr. 465, Meldunek sytuacyjny 25/32 na 1-15 XII 1932, Inspektorat Straży Granicznej Jasło, 17 XII 1932, k. 21-22.

${ }^{43}$ Ibidem, spr. 714, Charakterystyka terenu Komisariatu Straży Granicznej Ludwikówka przesłana na rozkaz Kierownika Inspektoratu Straży Granicznej Stryj, 14 I 1935, k. 19.

${ }^{44}$ Ibidem, spr. 348, Półmiesięczne sprawozdanie służby informacyjnej na dzień 10 IV 1930 r., 22 Inspektorat Straży Granicznej, k. 8.

${ }^{45}$ Ibidem, spr. 473, Inspektorat Graniczny Stryj, Przemyśl 21 VI 1932, k. 13.

${ }^{46}$ Ibidem, spr. 455b, Meldunek sytuacyjny nr 4 na dzień 12 II 1932, Inspektorat Straży Granicznej Nowy Targ, k. 22.

${ }^{47}$ Ibidem, spr. 407, Meldunek sytuacyjny nr 8 z dnia 9 III 1931, Inspektorat Straży Granicznej Nowy Targ, s. 26.

${ }^{48}$ Ibidem, spr. 595, Meldunek sytuacyjny nr 16 za 1-30 XI 1934, Inspektorat Straży Granicznej Nowy Targ, k. 34.

${ }^{49}$ Ibidem, spr. 249, Meldunek sytuacyjny nr 43 na dzień 26 V 1930, Małopolski Inspektorat Okręgowy Straży Granicznej w Sanoku, k. 198. 
Po śmierci Piłsudskiego wyznaczone zostały nabożeństwa. Niektórzy księża odprawili je wcześniej, „tak, że gdy ludność przybyła do cerkwi było już po nabożeństwie" ${ }^{\circ 0}$. 11 listopada, w dniu obchodów odzyskania niepodległości państwa polskiego, „ks. Gr.-kat. Eljaszewski ze Sławska w tym właśnie czasie, gdy miał odprawiać okolicznościowe nabożeństwo w miejscowej cerkwi zają się pogrzebem zmarłego mieszkańca ze Sławska pomimo tego, że pogrzeb zmarłego miał się odbyć w dniu $9 \mathrm{bm}$. Ks. Eljaszewski tendencyjnie pogrzeb odłożył na dzień 11 bm., żeby nie odprawiać nabożeństwa z okazji święta narodowego"51.

W polu zainteresowania księży greckokatolickich znalazły się również starania o szkoły narodowe i ich wsparcie finansowe. W tej kwestii księża współdziałali z organizacjami gospodarczymi, czego przykład stanowi działalność ks. Słupiejki, który „,wywarł wpływ na kupiectwo w Żabiu w ten sposób, że opodatkował na rzecz Ridnej Szkoły kupców 1\% dochodów od zakupionego towaru przez Ukraińców" ${ }^{2}$. Powszechne były wezwania do wnoszenia petycji przez rodziców o utworzenie szkół wyłącznie z językiem ukraińskim. Działania te odnosiły pożądane skutki i były związane z akcja plebiscytową mająca miejsce na szeroka skalę w całej Galicji Wschodniej ${ }^{53}$. W miejscowościach, w których aktywnie działali księża i nauczyciele, Straż Graniczna zauważała większy odsetek petycji o utworzenie szkół narodowych. Dochodziło także do sytuacji, w których wójt gminy narodowości ukraińskiej, zobowiązany do zatwierdzenia deklaracji rodziców, odmawiał, kiedy nie były wypełnione na korzyść języka ukraińskiego ${ }^{54}$. Kwestia, która została poruszona już wcześniej, a mianowicie rozgraniczenie między ludnością ukraińską i rusińska, również uwidoczniła się w tym wypadku: „w ostatnim czasie zauważono, że gr-kat. księża wspólnie z nauczycielstwem ruskim prowadzą silną agitację za zniesieniem w szkołach powszechnych nauczania j. ruskiego i za wprowadzaniem na jego miejsce j. ukraińskiego" ${ }^{\text {. }}$.

${ }^{50}$ Ibidem, spr. 671, Meldunek sytuacyjny nr 5/35 za 1-31 V 1935, Inspektorat Straży Granicznej Kołomyja, 2 VI 1935, k. 32.

${ }^{51}$ Ibidem, spr. 464, Meldunek sytuacyjny nr 23/32 za 1-15 XI 1932, Inspektorat Graniczny Stryj, 17 XI 1932, k. 27.

${ }^{52}$ Ibidem, spr. 671, Meldunek sytuacyjny nr 5/35 za 1-31 V 1935, Inspektorat Straży Granicznej Kołomyja, 2 VI 1935, k. 32.

${ }_{53}$ Zob. K. Sanojca, Relacje polsko-ukrainskie w szkolnictwie państwowym południowo-wschodnich województw Drugiej Rzeczypospolitej, Kraków 2013.

${ }^{54}$ CDIAUL, f. 204, op. 1, spr. 594, Meldunek sytuacyjny nr 14/34 za 1-30 XI 1934, Inspektorat Straży Granicznej Jasło, k. 35.

${ }^{55}$ Ibidem, spr. 465, Meldunek sytuacyjny nr 26 za czas 16-31 XII 1932, Inspektorat Straży Granicznej Sambor, 2 I 1933, k. 44. 


\section{Kwestia Czechosłowacji}

Biorac pod uwagę kwestię bezpieczeństwa na granicach, kluczową rolę odgrywały kontakty z sasiadami i działania na przedpolu, czyli w pasie granicznym leżącym po stronie państwa ościennego. Obiektem zainteresowania Małopolskiego Inspektoratu Okręgowego Straży Granicznej stała się przede wszystkim Czechosłowacja. Po zakończeniu I wojny światowej relacje między II RP a Czechosłowacją nie układały się pomyślnie. Rywalizacja o hegemonię w Europie Środkowo-Wschodniej, spór o Ślask Cieszyński, popieranie Rosji przez rząd w Pradze (jako sprzymierzeńca przeciwko Niemcom) ${ }^{56}$, ale także zatargi w kwestii ukraińskiej wzmagały wzajemną nieufność. Dość wspomnieć o wsparciu, zarówno ze strony rządu czechosłowackiego, jak i emigrantów ukraińskich przebywajaccych w Czechosłowacji, na rzecz działaczy OUN ${ }^{57}$. Broń, materiały wybuchowe oraz czasopisma i ulotki propagandowe płynęły do Polski kilkoma szlakami. Czechosłowacja popierała jednak ukraińskich nacjonalistów dopóty, dopóki ostrze ich aktywności skupione było jedynie przeciw Polsce. Z czasem działania OUN bezpośrednio na terytorium Rusi Zakarpackiej, dążące do wzmocnienia świadomości narodowej mieszkających tam Rusinów, dały się we znaki również rządowi w Pradze. W związku z tym coraz częściej władze czeskie wydawały zarządzenia organom bezpieczeństwa prowadzenia „ścisłej inwigilacji i obserwacji nad ruchem organizacji ukraińskich" ${ }^{\text {" }}$, a także współpracowały w tym zakresie z władzami polskimi. Przede wszystkim prowadzono akcję usuwania Ukraińców ze Straży Granicznej, a także „przeprowadzona pozostała redukcja sił nauczycielskich narodowości ukraińskiej i w miejsce tych posady obsadzono nauczycielami narodowości czeskiej" ${ }^{59}$. Według doniesień podejmowano również próby wzmacniania ruchu Rusinów, „tworząc partie ruskich faszystów. Ruch ten jest popierany przez władze czeskie i ma na celu rozbicie i osłabienie wzmagającego się ukraińskiego ruchu narodowego"60. Także strona polska popierała ruch rusofilski na terenie Rusi Zakarpackiej z tych samych powodów ${ }^{61}$.

Również dobrze rozwinięte szkolnictwo wyższe ukraińskie w Czechosłowacji zasilało OUN. Jednocześnie istniało w kołach politycznych Czechosłowacji

56 Szerzej na temat współpracy Pragi z Moskwą zob. M. Jarnecki, P. Kołakowski, „Ukraiński Piemont”. Ruś Zakarpacka w okresie autonomii 1938-1939, Warszawa 2017, s. 103-106.

${ }^{57}$ A.A. Zięba, Lobbing dla Ukrainy $w$ Europie międzywojennej. Ukraińskie Biuro Prasowe $w$ Londynie oraz jego konkurenci polityczni (do roku 1932), Kraków 2010, s. 139-141.

58 CDIAUL, f. 204, op. 1, spr. 460, Meldunek sytuacyjny nr 15 za 1-15 VII 1932, Inspektorat Graniczny Stryj, 16 VI 1932, k. 21.

${ }^{59}$ Ibidem, spr. 462, Meldunek sytuacyjny nr 20 za 16-30 IX 1932, Inspektorat Graniczny Stryj, 1 X 1932, k. 44.

${ }^{60}$ Ibidem, spr. 599, Meldunek sytuacyjny nr 9/34 za 1-15 V 1934, Inspektorat Graniczny Stryj, 16 V 1934, k. 89.

${ }^{61}$ M. Jarnecki, P. Kołakowski, op. cit., s. 108. 
przekonanie, że ukraiński ruch separatystyczny należy wspierać, przynajmniej częściowo, jako broń, która w przyszłości można wykorzystać przeciwko Polsce i Rosji ${ }^{62}$. Umożliwiano także organizację zjazdów ukraińskich nacjonalistów, co w Polsce było praktycznie nierealne. Jedno z takich spotkań miało odbyć się w kwietniu 1931 r. w przygranicznej miejscowości Berechova, na które zaproszono polską delegację OUN. Zebraniu miał przewodzić Jewhen Konowalec, przywódca ruchu nacjonalistycznego, a jednym z celów było ogłoszenie bojkotu biskupa diecezji stanisławowskiej ks. Grzegorza Chomyszyna, który realizował politykę porozumienia z polskimi władzami ${ }^{63}$. Rząd w Pradze prowadził więc dwulicową akcję. Wspieranie OUN nie przeszkadzało mu w przekonywaniu Warszawy, że nie ma żadnych kontaktów z działaczami OUN, szczególnie w kontekście zabójstwa ministra Bronisława Pierackiego w 1934 r. i przekazaniu władzom polskim przez stronę czeską tzw. Archiwum Senyka ${ }^{64}$. Co ciekawe, propaganda ukraińska ukazywała rząd czechosłowacki jako przeciwwage dla opresyjnego rządu w Warszawie, przywołując choćby przykład szkolnictwa wyższego. Analizując jednak sprawozdania z przedpola, obraz ten przedstawia się zgoła inaczej. Liczne doniesienia wskazywały na niezadowolenie ludności Rusi Zakarpackiej z rządów czechosłowackich. Na obu stronach najsilniej odbiła się sprawa autonomii obiecanej Ukraińcom z Zakarpacia. Wskazywały na to jednoznaczne deklaracje rządu:

W dniu 4-6 maja 1934 objeżdżał Ruś Podkarpacką Minister Spraw Zagranicznych i Wewnętrznych, [Edward] Benesz. Na zorganizowanych wiecach przybyłym delegacjom zapowiedziano, że w najbliższym czasie Ruś Podkarpacka otrzyma autonomię, która będzie wprowadzona stopniowo i obejmie szkolnictwo, wyznanie i administrację. Minister Benesz zaznaczył, że Czechosłowacja nie anektowała Rusi Podkarpackiej, lecz po wojnie światowej musiała się nią zaopiekować, gdyż takowa nie mogła się utrzymać jako samodzielne państwo i prędzej czy później zostałaby zajęta przez któregoś z sąsiadów ${ }^{65}$.

Taktyka ta opóźniała przyznanie tego, co od początku, według doniesień Straży Granicznej, było przesądzone - autonomii nie planowano. Wszelkie próby podejmowane przez działaczy ukraińskich spełzły na niczym:

Wszyscy prawie Ukraińcy, którzy uciekli z Polski zajmują w Czechosłowacji przeważnie stanowiska urzędnicze. Partia ukraińska w ostatnich czasach chciała wymóc w Czechach swoją autonomię, przez posła swego Kuriatnika, lecz na obradach poselskich wniosek ten został odrzucony, gdyż Czesi jako też obywatele czescy zamieszkali

${ }^{62}$ K. Lewandowski, Sprawa ukraińska $w$ polityce zagranicznej Czechostowacji $w$ latach 1918-1932, Wrocław 1974, s. 289-293.

${ }^{63}$ CDIAUL, f. 204, op. 1, spr. 408, Doniesienie Inspektoratu Straży Granicznej w Samborze, 14 IV 1931, k. 31.

${ }^{64}$ W. Żeleński, Zabójstwo Ministra Pierackiego, „Zeszyty Historyczne” 1973, z. 25, s. 30-32.

${ }^{65}$ CDIAUL, f. 204, op. 1, spr. 588, k. 102. 
nad rzeką Cisą nienawidzą Ukraińców i nie chcą nawet słyszeć ukraińskiej mowy i pisma, a nawet obywatele $\mathrm{z}$ nad Cisy chca Ukraińców całkiem wyrugować ze swoich obszarów. Z tego powodu wśród Ukraińców jest wielkie rozgoryczenie i kto wie czy nie przyjdzie pomiędzy Ukraińcami i Czechosłowacją do tego jak pomiędzy Ukraińcami a Polską w r. 1918 i 1919 tj. do wojny ukraińsko-czechosłowackiej66.

W wyniku prowadzonych wywiadów wśród miejscowej ludności strażnicy graniczni wynosili obraz inny niż ten, który propagowało OUN. Według nich ludność zamieszkująca Ruś Zakarpacka miała wiele powodów, aby nie popierać władzy w Pradze, a najczęściej oskarżenia w kierunku władz wiązały się z kwestiami ekonomicznymi, gdyż „ludność na przedpolu jest rozgoryczona z powodu wprowadzenia w Czechosłowacji monopolu zbożowego, pobierania wysokich podatków i przeprowadzania bezwzględnych egzekucji należytości podatkowych. Wśród ludności krążą ciche wieści o zamiarach odebrania przez Polskę pewnej połaci kraju, który dawniej do Polski należał". Podobne uwagi kierowane były pod adresem czechosłowackich strażników granicznych ,ze względu na to, że pobierają wysokie uposażenie służbowe a nic nie robia, tylko rozpijają się po knajpach [...] a uciśnięty biedny naród ruski pokrywa wszelkie koszty utrzymania tak Straży Granicznej jak i Żandarmerii"67. Ostrze tych oskarżeń kierowane było jednak również do Polski: „W związku z wyborami, które się odbyły w Republice Czechosłowackiej na terenie Zakarpackiej Rusi do Sejmu i Senatu, agitatorzy na wygłoszonych wiecach przedwyborczych mówili o ucisku ludności ruskiej w Polsce, a mianowicie: że ludność ruska zamieszkała na terenie Polski cierpi głód, nie wolno jej mówić po rusku, dzieciom w szkołach nie wolno uczyć w ogóle pobierać nauki w języku ruskim, gdyż władze polskie absolutnie na to nie pozwalaja" ${ }^{68}$. Takie opinie siały zamęt po obu stronach, a nacjonaliści wykorzystywali je do własnych celów.

\section{Zakończenie}

Ochrona granic była jednym z kluczowych elementów zapewnienia bezpieczeństwa oraz rozwoju ekonomicznego II Rzeczypospolitej. Dwoistość systemu granicznego sprzyjać miała skuteczniejszej obronie państwa. Było to szczególnie istotne przy geopolitycznych uwarunkowaniach położenia II RP, otoczonej przez państwa nastawione wrogo: Niemcy, Czechosłowację, ZSRR. Bilans działań Straży Granicznej w tym zakresie przedstawiał się niejednoznacznie. Przyczyniły się do tego braki kadrowe, słabe przygotowanie zawodowe, niedostateczne wyposażenie techniczne oraz trudności w pozyskiwaniu odpowiednich

\footnotetext{
${ }^{66}$ Ibidem, spr. 546, Placówka Straży Granicznej I Linii Wyszków, 24 I 1933, k. 1.

${ }^{67}$ Ibidem.

${ }^{68}$ Ibidem, spr. 671, Meldunek sytuacyjny nr 5/35 za 1-31 V 1935, Komisariat Straży Granicznej Ławoczne, 31 V 1935, k. 14.
} 
konfidentów i informatorów, którzy mieli stanowić trzon działań. Zdecydowanie większe sukcesy osiagnęli na polu walki z przemytnictwem. Rzadko jednak udawało się złapać osoby przewożące broń czy ulotki antypaństwowe. Jednocześnie materiały przekazane wywiadowi wojskowemu przyczyniły się do sprawniejszego działania na całym terenie Galicji Wschodniej. Specyfika ziem pogranicza i ludności ukraińskiej tam mieszkającej sprzyjała większej aktywności nacjonalistów z OUN. Słabe uświadomienie kulturalne i społeczne przekładało się na ułatwienie im agitacji wśród miejscowej ludności. Ukraiński nacjonalizm odegrał jednak znacząca rolę w budowaniu świadomości narodowej, szczególnie przy współpracy z księżmi oraz nauczycielami. Wroga działalność organizacji nacjonalistycznych, do których ciąnęła ludność ukraińska, szczególnie młodzież, jedynie potęgowała coraz ostrzejszą politykę państwa polskiego. Podejmowane próby współpracy z lojalną częścią Ukraińców były niewystarczające, zwłaszcza przy rosnącej aktywności nacjonalistów.

\section{Streszczenie}

Ochrona granic państwowych była jednym z najpoważniejszych zadań, jakie stanęły przed II Rzeczapospolitą w kwestii zapewnienia bezpieczeństwa wewnętrznego. W celu usprawnienia jej organizacji przeszła przez kilka etapów rozwoju, co doprowadziło do ostatecznego podziału granic na dwie części i podporządkowania ich ze wschodniej strony Korpusowi Ochrony Pogranicza, z północnej, zachodniej i południowej - Straży Granicznej. W tym wypadku interesująca jest jedynie część tej ostatniej formacji, której inspektoraty znajdowały się na terenie Małopolski Wschodniej. Jeden z aspektów działalności Małopolskiego Inspektoratu Okręgowego Straży Granicznej stanowiło zapobieganie antypaństwowej aktywności politycznej. Takim zagrożeniem była m.in. Organizacja Ukraińskich Nacjonalistów, której celem stało się, za pomoca nielegalnych metod, doprowadzenie do ukraińskiego powstania i oderwania ziem Małopolski Wschodniej od Polski. Starała się to osiagnąć również za pomoca agitacji wśród miejscowej ludności ukraińskiej. W tym kontekście celem niniejszego tekstu jest ukazanie pogranicza jako terenu, który wyróżniał się odrębną specyfika, szczególnie w kwestii stosunków narodowościowych, kształtowania się tożsamości narodowej, a także kontaktów z państwami ościennymi. Artykuł stanowi próbę interpretacji dokumentów wytworzonych przez Straż Graniczną w latach 1930-1935, które dotychczas nie znalazły się w obiegu naukowym.

\section{Security on the frontier. OUN's activity between 1930 and 1935 in the light of situation reports of the (Eastern) Lesser Poland Regional Inspectorate of the Border Guard}

The protection of the state borders was one of the most important tasks faced by the Second Republic of Poland. In order to make it more efficient, it went through several stages of development, which finally lead to a division of the Polish border into two sections: the eastern one, supervised by the Border Protection Corps (Korpus Ochrony Pogranicza, or $\mathrm{KOP}$ ); and the northern-western and southern one, under the protection of the Border Guard (Straz Graniczna). In the latter case we are interested only in its part with regional inspectorates in the area of Eastern Lesser Poland (Matopolska Wschodnia). One of the aspects of operations of the Lesser Poland Regional Inspectorate of the Border Guard was to 
prevent political activities against the state, carried out by, among others, the Organization of Ukrainian Nationalists seeking to incite, through illegal methods, an Ukrainian uprising and to separate the territory of Eastern Lesser Poland from the Polish State. To this end, OUN engaged in agitation among the local Ukrainian population. In this context, the purpose of the study is to present the borderland as an area with its own, specific national identity, national relations, and also contacts with the neighbouring states. The article is an attempt at the author' interpretation of documents issued by the Border Guard between 1930 and 1935 that have not entered the scientific circulation so far.

\section{Bibliografia}

Chojnowski A., Koncepcje polityki narodowościowej rzadów polskich w latach 1921-1939, Wrocław 1979.

Gibiec M., Proces kształtowania się tożsamości narodowej na pograniczu polsko-rumuńsko-czechosłowackim w kontekście bezpieczeństwa II Rzeczypospolitej. Analiza dokumentów Inspektoratu Granicznego „Kołomyja” z lat 1928-1935, w: Kołomyja, Pokucie, Huculszczyzna $w$ II Rzeczypospolitej. Wybrane zagadnienia, red. nauk. A.A. Ostanek, A. Smoliński, Warszawa 2017, s. 64-80.

Hryciuk G., Przemiany narodowościowe i ludnościowe w Galicji Wschodniej i na Wotyniu w latach 1931-1948, Toruń 2005.

Jarnecki M., Kołakowski P., „Ukrainski Piemont”. Ruś Zakarpacka w okresie autonomii 1938-1939, Warszawa 2017.

Kula H.M., Polska Straż Graniczna w latach 1928-1939, Warszawa 1994.

Lewandowski K., Sprawa ukraińska w polityce zagranicznej Czechostowacji $w$ latach 19181932, Wrocław 1974.

Litwiński R., Policja wobec UWO i OUN w II Rzeczpospolitej, „Biuletyn Instytutu Pamięci Narodowej” 2010, nr 12 (121).

Sanojca K., Relacje polsko-ukraińskie w szkolnictwie państwowym południowo-wschodnich województw Drugiej Rzeczypospolitej, Kraków 2013.

Wysocki R., Organizacja Ukraińskich Nacjonalistów w Polsce w latach 1929-1939, Lublin 2003.

Zięba A.A., Lobbing dla Ukrainy w Europie międzywojennej. Ukraińskie Biuro Prasowe $w$ Londynie oraz jego konkurenci polityczni (do roku 1932), Kraków 2010.

Żeleński W., Zabójstwo Ministra Pierackiego, „Zeszyty Historyczne” 1973, z. 25.

Bi og r a m: Magdalena Gibiec - historyk, doktorantka w Instytucie Historycznym Uniwersytetu Wrocławskiego. Zainteresowania badawcze: bezpieczeństwo wewnętrzne II Rzeczypospolitej, polityka narodowościowa wobec mniejszości ukraińskiej, działalność administracji terytorialnej wobec legalnych i nielegalnych organizacji ukraińskich na terenie Galicji Wschodniej, ukraińska tożsamość narodowa. E-mail: magdalena.gibiec@uwr.edu.pl. 